\title{
THE
}

$1-1-2000$

\section{Challenges in Building an Incremental, Multi-Year Information Literacy Plan}

Mary C. MacDonald

University of Rhode Island, marymac@uri.edu

Andrée J. Rathemacher

University of Rhode Island, andree@uri.edu

Joanna M. Burkhardt

University of Rhode Island, jburkhardt@uri.edu

Follow this and additional works at: https://digitalcommons.uri.edu/lib_ts_pubs

Part of the Library and Information Science Commons

\section{Citation/Publisher Attribution}

MacDonald, Mary C., Andrée J. Rathemacher, and Joanna M. Burkhardt. "Challenges in Building an Incremental, Multi-Year Information Literacy Plan." , (2000). doi: 10.1108/00907320010345123.

This Article is brought to you for free and open access by the Technical Services at DigitalCommons@URI. It has been accepted for inclusion in Technical Services Department Faculty Publications by an authorized administrator of DigitalCommons@URI. For more information, please contact digitalcommons-group@uri.edu. 


\title{
Challenges in Building an Incremental, Multi-Year Information Literacy Plan
}

\begin{abstract}
The authors discuss the plan for building an incremental, multi-year information literacy program at the University of Rhode Island. Review of the current library instruction program leads to why and how they plan to change the program by focusing on the concepts of understanding what information is in addition to learning how to gather, evaluate, and use information. The Draft Plan for Information Literacy at the University of Rhode Island Libraries addresses the information and research needs of undergraduate and graduate students as well as faculty needs. The development of creditbearing courses in information literacy, the creation of information literacy modules for specific disciplines and the Draft Plan for Information Literacy are discussed.
\end{abstract}

\section{Keywords}

information literacy; instruction; resource-based learning; curriculum; University of Rhode Island.

\section{Introduction}

The beginnings of a comprehensive plan for information literacy at the University of Rhode Island date to March 1998. Reference librarians had been informally discussing ways to improve the library's instruction program. The interest of the new Vice Provost for Information / Dean of University Libraries Paul B. Gandel in developing an information literacy program and offering credit-generating courses in the library 
provided the avenue and support we needed for these thoughts to come together into a plan. A group of interested reference librarians met with the Vice Provost / Dean to address information literacy goals and to investigate how they could best be integrated into the curriculum. The first step in the planning process was to discuss what elements of the current library instruction program needed to change and why.

\section{Current library instruction program}

Library faculty in the University Library are actively engaged in bibliographic instruction. In academic year 1998/99, eight reference librarians and three library science graduate students taught 325 library instruction sessions, reaching a total of 7,323 students out of a student population of approximately 14,000. Since academic year 1995/96, these numbers have been growing steadily, with the number of classes taught increasing by $15 \%$ and the number of students reached increasing by $37 \%$.

Almost half of all bibliographic instruction classes taught in 1998/99 were for sections of two freshman classes. Each semester, reference librarians schedule "bibliographic instruction blitzes" for URI 101: Traditions and Transformations, a onecredit course that familiarizes first year students with college life and for WRT 101: Composition, an introductory writing course. In URI 101, librarians introduce students to the online catalog, and in WRT 101 students are familiarized with a core, interdisciplinary periodical database.

In addition to these "blitzes", individual reference librarians teach "one-shot" BI's in their areas of expertise. In 1998/99, librarians taught 160 of these subject-specific classes, which accounted for $49 \%$ of all classes taught. One-shot BI's are usually 
requested by faculty members who contact the appropriate member of the library faculty to arrange a session, and instruction tends to focus on showing students the particular tools that will help them complete an assignment for the course. This system of customized library instruction does not operate with an explicit plan or strategy. It depends almost entirely on individual faculty members taking the initiative to request a session in the library. In addition, "one-shot" instruction de-emphasizes a conceptual understanding of information, the development of broadly-applicable research strategies, and the critical evaluation of information in favor of a "which-button-do-I-push-next" approach to demonstrating sources needed to complete particular information-gathering tasks.

Despite reaching large numbers of students, the "one-shot" approach to library instruction misses even more. Some students receive repetitive instruction while others receive only minimal instruction, or none at all. The amount of instruction a given student receives tends to vary by discipline and even by course. For example, business students receive more instruction than do engineering students, and within the College of Business, students taking courses in marketing receive more library instruction than students in finance courses do. While some of the variation in levels of instruction results from varying research requirements of individual programs, part is also explained by the level of initiative taken by faculty throughout campus as well as within the library.

In contrast to the "one-shot" BI's just described, library instruction for the URI 101 and WRT 101 courses is more programmatic, in that a pre-defined set of concepts and resources is covered and, at least in theory, every student enrolled in these courses is reached. However, there are shortcomings here as well. Each URI 101 and WRT 101 
class receives only 50 minutes or at most 1 hour and 15 minutes of instruction, which allows for teaching only a small fraction of what students need to know. In addition, it often seems as if students do not retain much of what is taught to them during these classes.

Finally, both "one-shot” BI's and the URI 101 and WRT 101 "blitzes" are very time and resource intensive. For "one-shot" classes, librarians prepare customized presentations and lessons geared to the specific assignment at hand. The content of the URI 101 and WRT 101 sessions is standardized, but scheduling and teaching the large number of sections each semester is a strain at current levels of staffing.

\section{Why change?}

There were two pieces of evidence that provoked us into changing the program. First, knowing how little students seemed to retain of what was taught told us we needed to improve the instruction itself. Second, realizing how many students never received any instruction troubled us. In discussing these two factors, a vision for a new program began to emerge. We would fortify and improve the program by focusing primarily on the concepts of information and research — the skills would follow along as the tools they are intended to be.

Several key documents played a major role in helping us redesign our library instruction program into an information literacy program. We examined the literature, including both the 1989 “ALA Presidential Committee on Information Literacy Final Report" (American Library Association, 1989) and the recently approved "ACRL Information Literacy Competency Standards for Higher Education" (Association of 
College and Research Libraries, 2000). These guidelines and standards provided a welldefined map for us to follow. In addition, Patricia Breivik's research in Student Learning in the Information Age reinforced our belief that "classroom business-as-usual cannot be tolerated on campuses that place a high value on student learning" (Breivik, 1998). Finally, as suggested by Shapiro and Hughes (Shapiro and Hughes, 1996), we came to the conclusion that we should approach information literacy as a new liberal art that should be infused across the campus. Many librarians teach in a classroom setting, though we are not always considered teachers in the traditional sense. We maintain that not only do we teach in the traditional sense, but also we teach anywhere and any time we interact with information seekers. Our teaching is the connection between subjectspecific courses and the research that is produced by students. This new liberal art is clearly in our venue.

We had guidelines, standards and a strong rationale for changing. The Carnegie Foundation's 1998 Boyer Report "Reinventing Undergraduate Education: A Blueprint for America's Research Universities" (Boyer Commission on Educating Undergraduates in the Research University, 1998) recommends ten practices for improving undergraduate education. Boyer's number one recommendation is "Make Research Based Learning the Standard". Research based learning involves learning through inquiry and problemsolving. Our goal is to provide students with a learning method that will allow them a sense of discovery and empowerment in their learning that will produce learning from within. If students at the University of Rhode Island are to truly develop "capabilities as critical and independent thinkers" (University of Rhode Island, 1996) then we must extend and enhance students' opportunities to do so. "Resource-based learning is a 
common sense approach to learning. If students are to continue learning throughout their lives, they must be able to access, evaluate, organize and present information from all the real-world sources existing in today's information society.” (Breivik, 1998). “The abilities to identify, analyze, and resolve problems will prove invaluable in professional life and citizenship" (Boyer Commission on Educating Undergraduates in the Research University, 1998).

Finally, we developed a working definition of information literacy for the University of Rhode Island. "Information literacy is the ability to understand the concepts and values of information in the context of data, information and knowledge. Further, it is the ability to understand where information comes from, where it goes and what the relationship is between the learner and the information world. It means being able to gather, analyze and use information in an effective and meaningful manner.” This definition was intended as a working model to present to the library faculty as a starting point.

\section{The Information Literacy Plan at URI}

The next step was to shape what we had learned about information literacy programs into a planning document that we could use to share and discuss ideas with our colleagues and the University community at large. In June of 1999, through the auspices of the Library Strategic Planning Steering Committee, and at the request of the Director of Libraries, Artemis G. Kirk, we created the Task Force for Teaching and Research. Through the work of the Task Force we developed a draft plan that addressed building an incremental, multi-tiered information literacy program, recognizing that any information 
literacy plan needed to be far reaching so as to include as many instructional methods as possible and to reach as much of the campus community as possible.

We researched what other academic institutions had done to introduce and facilitate their information literacy programs. The use of advisory councils for oversight, web tutorials as primary or supplemental curriculum materials and faculty/librarian collaborations to enhance the curriculum are prevalent. We looked to the experiences of the University of California at Berkeley, Florida International University, and the University of Arizona for information about institutions which utilize the concept of teaching library councils or advisory boards, which provide oversight for campus-wide programs.

During the previous academic year we had designed and taught a one-credit course, Special Topics in Information Literacy, and designed a three-credit course, Introduction to Information Literacy. These credit bearing courses are the heart of our program but hardly the entire body. The attention that credit-bearing courses receive is a good way in which to announce the entire program to the campus community.

In the future, we plan to incorporate a web tutorial for classroom teaching and distance education students. The University of Rhode Island uses WebCT for its virtual courses. The University of Wisconsin-Parkside, the University of Texas, James Madison University, the University of Arizona, and the SUNY system have all developed successful web tutorials. Currently we use the web to access some course materials, and we are considering WebCT as an option. The Task Force felt that we needed much more time, staff and funding before we could consider a fully developed web tutorial. 
We gained insight into librarian/faculty collaborations from programs at Earlham College, Towson University, Wayne State University, Seattle Central Community College and the University of Iowa. Several faculty/librarian collaborations are in progress at URI, and more are anticipated in the next academic year. While we have traditionally worked with course instructors to design each library instruction session, our goal now is to "teach the teacher" how to build information literacy concepts into library and other class assignments.

Early in the spring semester of 2000, our Vice Provost / Dean invited us to present the Draft Information Literacy Plan to the Council of Deans. The Council was very interested in our initiative, particularly the Deans of University College and the College of Continuing Education. One Dean was prompted to ask, "How many sections of the three-credit course can you offer?" With this interest and support, our information literacy program plans were well underway. Further discussion with both of these Deans have accelerated interest in information literacy on campus.

Since the first Draft Plan in June 1999, there have been six revisions. In February 2000 the Library Strategic Planning Steering Committee dismissed the Task Force for Teaching and Research with the provision that we present a final report in April. The Draft Information Literacy Plan is now in the venue of the Public Services Department faculty of the University Libraries. After final revisions are completed, we will bring it to the full faculty for approval. While we are excited and pleased with the progress we have made already, it is important to take care and time in further development of the plan.

The Draft Plan includes the following objectives: 
- Develop a shared definition of information literacy for the University of Rhode Island.

- Develop and introduce an incremental, four-year-plus program for student mastery of information literacy concepts and skills.

- Implement the program by working with teaching faculty outside the Libraries.

- Provide more teaching labs, locations, and facilities.

- Develop a core group of library faculty specifically for teaching.

For each objective we developed action items, time frames and responsible parties. While these are still in a fluid state, we have made considerable progress in envisioning new models for the delivery of information literacy across the curriculum.

According to the Draft Plan, students at the freshman, sophomore, and junior levels would have the option of achieving information literacy competency by fulfilling a series of instructional modules or by taking the 3-credit course Library 120: Introduction to Information Literacy. A 1-credit course Library 140: Special Topics in Information Literacy is designed to be subject specific and possibly aligned with particular courses in other disciplines and is recommended for those students who have declared majors. The senior year of the information literacy program would require completing a capstone portfolio project, in conjunction with the capstone course required for graduation in the student's major. Librarians will design project guidelines for the students and project assessment tools for their professors.

The Draft Plan also addresses information literacy needs of graduate students and faculty by calling for regularly scheduled orientations, seminars and workshops in 
specific disciplines. A model for these is BIO508: Seminar in Biological Literature. This course covers the literature of the life sciences and is offered each spring semester by faculty librarian J. Lawrence Kelland. BIO 508 offers students a wide choice of semesterlong projects to fulfill, which accommodates the varying interests and needs of the upperclassmen and graduate students who take the course. Finally, the Draft Plan calls for the creation of a learning laboratory dedicated to the support of librarian/faculty collaboration in the design of courses and assignments.

\section{The courses}

While the Draft Plan for Information Literacy at the University of Rhode Island is a comprehensive document that addresses working toward information literacy on a number of levels, the credit courses are truly the heart of the program. They are also the source of our experience and accomplishments in information literacy instruction under the auspices of the new plan, thus far.

\section{LIB 140: Special Topics in Information Literacy}

LIB 140: Special Topics in Information Literacy was the first credit-generating course specifically developed and taught as part of the Libraries' emerging information literacy program. LIB 140 is a one-credit course that addresses information tools and concepts in a particular subject area, e.g. business, and is intended to run concurrently with a course in that discipline. The genesis of this model came from the idea that developing partnerships between library faculty and faculty teaching core courses in 
major disciplines was one of the most promising ways of successfully integrating information literacy into the curriculum.

In Spring Semester 1999, Andrée J. Rathemacher and Mary C. MacDonald, two library faculty members, team-taught two sections of LIB 140 with a focus on business information. Their sections were linked to Professor of Management Clay V. Sink’s MGT 110: Introduction to Business class. Students who enrolled in Professor Sink's two sections of MGT 110 were also required to register for LIB 140. Both sections of LIB 140 were fully enrolled, with 25 students each.

LIB 140 covered general information concepts such as catalogs, subject headings, indexes, etc. as well as specific topics related to business, such as company and industry information. The class was taught in a workshop style as much as possible, with most class periods beginning with an introduction to the topic, e.g. company financial information, after which students gathered into groups and worked hands-on with the information resources to complete an in-class worksheet. Instead of a final examination, every student in the class wrote a "Memo-to-Your-Manager" on a current issue related to business. The memo was intended to serve as an assessment tool by which students would demonstrate how well they had mastered the ability to articulate their information needs, to develop search strategies, and to find, critically evaluate, and communicate information.

LIB 140 received very positive evaluations from students, although some clearly resented having been "forced" to enroll in the course. The results of a survey of the class by the University's Instructional Development Program revealed that $94 \%$ of the students surveyed thought they learned "a great deal" or "a fair amount," and 73\% rated the course 
"excellent" or "good." Some students felt that the course required too much work for one-credit, but most had more positive comments, such as: "It was not as bad as I first assumed! Some of the lessons actually helped me in my other classes!"; "I found it very helpful for my business classes and many other classes. Many students don't know how to do research. This class teaches that!"; and "I learned a lot in this course, and I know what I learned will help me a lot in my university and more future life [sic]. In my opinion, everybody has to learn what we studied in this course."

Students liked the "hands-on" nature of the class and made favorable comments about the worksheets, for example "the worksheets are fun; I like them." and "At first I thought these worksheets were stupid, but now that I have to do research for MGT 110, I realize how useful they are." Students did complain, however, when they felt that the instructors were doing too much talking or if they couldn't see the immediate applications of the material covered to their work in MGT 110. Also noteworthy was the fact that students seemed to resist the instructors' attempts to bring a more conceptual framework to the class through addressing, for example, the principles behind subject headings and descriptors, or why companies are required to disclose financial information, or why it is so important to evaluate information after finding it. This phenomenon made us wonder whether or not first-year students are ready to engage with information-related concepts at a more abstract level.

At the present time, our attention has shifted away from LIB 140 to our threecredit course, LIB 120, although we do intend to revisit LIB 140 in the future. There are a number of questions that need to be addressed first, before LIB 140 is revived. Perhaps the most significant question arises from a University decision that concurrent 
registration cannot be required of students: Without being connected to another course, would LIB 140, with only one-credit, attract students? Should we argue to have this decision prohibiting concurrent registration reversed, or should we increase the number of credit hours for LIB 140 and hope that it will then attract students on its own? Given that LIB 120 is seen as a natural precursor to the subject-specific LIB 140, and that most students are not heavily into subject-specific courses in their major area of study until the third year of college, should the level of LIB 140 be increased? Should the course be designated as "writing-intensive" so that it might be considered as an option for filling communications or writing requirements in specific programs of study? Given the growing demand for LIB 120, should we abandon LIB 140 altogether to concentrate our resources on LIB 120 and find alternative ways to deliver subject-specific information literacy skills?

\section{LIB 120: Introduction to Information Literacy}

LIB 120: Introduction to Information Literacy was the second credit-generating course developed and taught in the library's information literacy program. The course was developed as the natural precursor to LIB 140. LIB 120 was born out of the faculty's perceived need for students to have a broader and deeper understanding of information, information retrieval, and evaluation and analysis of information. In addition, the course stems from students' need to obtain this understanding early in their college careers. The course was developed by library faculty in consultation with other faculty who recognized the need for a stand-alone course in information literacy. 
Students express their frustration at the overwhelming nature of the information arena on a daily basis. Their confusion stems from the lack of systematic instruction in overlying concepts necessary to extract the specific information they need from the thousands of possible sources available. LIB 120 provides this instruction in concepts. Students are so eager to gain mastery of these concepts and skills that the first group was willing to take the course as an elective.

While teaching the first section of LIB 120 during the Fall of 1999 we petitioned for this course to fill a General Education requirement for University College in the area of English Communication. This initiative received the support of the library faculty, library administration, the Curricular Affairs Committee of the Faculty Senate, and the Faculty Senate itself. We expect the final signatures to be in place before the end of the Spring 2000 semester. This approval makes Library 120 one of only six courses that students can take to satisfy the communication requirement. This has broadened the usefulness of the course to the students and increased demand for seats in the class.

LIB 120 is a 3-credit course which focuses on a basic conceptual understanding of what information is, where it comes from, and how it is and can be used. The course goal is to create lifelong learners, problem solvers, and independent and critical thinkers. The course is based on active learning in the evolving world of information. It begins with a brief introduction to information in everyday life. As the course progresses, we lead students from the organization of information, to the different uses for information and the different audiences for which information is provided, to academic information tools. We discuss and demonstrate catalogs, indexes, subject headings, descriptors, keywords, and why all these things are useful. The Internet is explored as a separate unit, with 
concepts from other units re-emphasized for this specialized medium. Critical thinking skills and resource evaluation techniques are stressed throughout the course. Weekly inclass and take home exercises and worksheets provide reinforcement and practice in both skills and concepts.

The final project for the course is to provide a "paper trail" for research leading to a research paper. The research paper could be one assigned for another course, or just a topic of interest. We ask for a topic thesis statement, a list of search terms used, a notation of which ones "worked" and which ones did not. We ask what research tools were used, what information was found in each, what resources were used, and which of those provided material actually pertinent to the topic. We require a detailed outline of the paper or the paper itself and a complete bibliography.

The first section of LIB 120 was team taught by Mary C. MacDonald and Joanna M. Burkhardt during the Fall semester of 1999. The course was taught at the Providence campus of the University, which caters to older, non-traditional students. The average Providence campus student is 40, works full-time, and has a family. These students are very focused, motivated and enthusiastic. We felt that LIB 120 would get a fair trial and an honest evaluation from this population. We also felt that this group would better tolerate the vagaries and glitches associated with a new course.

Ten students began the course in September and nine remained. They were excited about the course and its content. They were eager and appreciative participants in class discussions and assignments. They took the subject and the work very seriously. The only complaint we heard was, "Why wasn't this course offered before?" Students volunteered to write letters to various Deans and Directors in support of the course. Our 
evaluations from this group were very encouraging and included many positive comments.

Two sections of LIB 120 were scheduled for the Spring 2000 semester. One section was held in Providence. The second section was held in Kingston. While the class in Providence was much the same during both semesters, the learning dynamic in Kingston proved to be quite different. The Kingston section was fully enrolled, with only two female students and two non-traditional students. The Kingston group appeared to be somewhat more computer savvy, but less inclined to stay focused for a three hour class. They were less shy about trying new things, but also less willing to speak up if they didn't understand something. This has lead to some on-the-spot modifications to the presentation of the course at the Kingston campus.

Pre- and post-tests have been administered to each class. While results are based on a limited number of students, it appears that students do improve their conceptual and mechanical skills after taking LIB 120. Student comments indicate that the importance and applicability of what they learned in LIB 120 became more and more evident and useful as their new knowledge was put into practice for other courses. Students who have completed the course have returned to tell us how valuable the course has been to them in other classes, at work, and at home.

Three sections of LIB 120 are scheduled for Fall 2000, two in Kingston and one in Providence. Discussions are underway with University College and with the Bachelor of General Studies program to integrate LIB 120 as a required course for all students. As demand drives availability, we expect to continue to add sections of LIB 120 each semester. 


\section{Information Literacy Modules}

While credit-generating courses are currently the focus of our plan for information literacy at the University, it is our vision that these courses will be supplemented by subject-specific “modules.” We conceive of information literacy modules as standardized "toolkits" containing information resources, research strategies, in-class exercises, assignments, etc. geared to particular fields, instructional areas, and topics. The modules will provide a concrete way for librarians and other teaching faculty to work together in delivering information literacy skills throughout the curriculum.

One example currently under discussion is the development of a module for graduate students of labor and industrial relations. The Labor Research Center, which offers a Master of Science in Labor Relations and Human Resources, has eliminated a previously required course on information sources and uses in labor relations and labor economics from their program. While they don't feel that a full three-credit course is necessary, they recognize the importance of their graduates having the skills to access the literature of the field, to find labor and economic statistics, and to trace legislation. To this end, the professor who previously taught the course has approached two librarians who have met with the class each semester to suggest that together they develop a series of modules, totaling about six hours, to deliver these necessary research skills.

Developing modules such as these to teach information literacy skills will enable us to reach more students than we can through credit courses or traditional bibliographic instruction alone because the modules can be delivered not only by the library faculty but also by other teaching faculty in consultation with librarians. We expect that modules will 
also eliminate much of the duplication inherent in our traditional bibliographic instruction program, because through the modules instruction will be structured around a set of predefined information literacy competencies instead of tailored to specific, often repetitive, class assignments.

We envision that the modules will have more or less standardized content, e.g. "Researching a Company" or "Drug Information," but will be able to be customized within their instructional context through the use of specific examples, exercises, information tools, and assignments. To a faculty member, choosing a module for his or her class will be like buying a particular make and model of automobile - the body and engine are the same, but the color of the car and options such as a sunroof or all-wheeldrive can be added. Initially, asking faculty who are interested in scheduling library instruction to pick from a standardized "menu" of modules will save a great deal of time that now is invested in preparing for customized one-shot classes. More important, however, teaching with the modules will ensure that all the concepts that have been identified as important in connection with that subject are covered.

Ultimately, we believe that for the information literacy modules to be relevant, they must be strategically linked to particular general education courses and to core courses in each discipline. For example, all junior business majors taking Management 301 could be required to complete a "Company Information" module and/or a "Business Research" module. Students could be tested on their mastery of the content of the module, with their scores becoming part of their grade for the course. It is our hope that required freshman and sophomore level modules could replace the URI 101 and WRT 101 "blitzes" and that junior level modules could eventually substitute for the majority of 
"one-shot" bibliographic instruction sessions. In this way, information literacy instruction can be woven into curriculums campus-wide, ensuring that all students receive the information skills they need at critical points in their college careers.

Such a plan will require working closely with other faculty in departments, colleges, and programs across campus and convincing them of the importance of integrating information gathering and evaluation skills into their programs of study. If we cannot instill in others the conviction that such skills are important, the modules will at best be nothing but substitutes for "one-shot" instruction sessions and will not reach all the students we would like them to.

\section{Conclusion}

We are still in the early stages of a full-grown information literacy program. Our Draft Plan is a work in progress, and many of our recommendations will take a great deal of collaboration, effort, and time to accomplish. Yet we now have the beginnings of what we hope will be a thriving information literacy program at the University of Rhode Island. As we move forward and implement additional pieces of the plan, we will gather support, suggestions, assistance, and impetus from many constituents.

The dynamic character of information is undeniable. We expect our plan to evolve as we gain experience. We hope to create a program which will offer the flexibility and adaptability to respond to that dynamism, incorporating changes in technology, education and culture as they occur. In the final analysis, we hope to incorporate a new and much needed understanding of information and information literacy into the University of Rhode Island college experience. This, in turn, will provide 
students with powerful skills and analytical expertise that they will use in all of their post-college pursuits. 


\section{Reference List}

American Library Association, Presidential Committee on Information Literacy (1989), Final Report, American Library Association, Chicago. <http://www.ala.org/acrl/nili/ilit1st.html> (3 Nov. 1999).

Association of College and Research Libraries (2000), Information Literacy Competency Standards for Higher Education, Association of College and Research Libraries, Chicago. <http://www.ala.org/acrl/ilcomstan.html> (9 Apr. 2000).

Boyer Commission on Educating Undergraduates in the Research University (1998), Reinventing Undergraduate Education: A Blueprint for America's Research Universities, State University of New York, Stony Brook, N.Y. $<$ http://notes.cc.sunysb.edu/Pres/boyer.nsf> (4 Nov. 1999).

Breivik, P.S. (1998), Student Learning in the Information Age, Oryx, Phoenix.

Shapiro, J.J. and Hughes, S.K. (1996), "Information literacy as a liberal art: enlightenment proposals for a new curriculum”, Educom Review, Vol. 31 No. 2. <www.educause.edu/pub/er/review/Articles/31231.html> (21 Oct. 1999).

University of Rhode Island (1996), "Mission Statement", University of Rhode Island, Kingston, R.I. <http://www.uri.edu/home/about/mission.html> (9 Apr. 2000). 